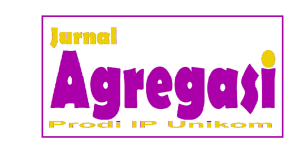

JURNAL AGREGASI

Jurnal Aksi Reformasi Government Dalam

Demokrasi

Volume 7- Nomor 2, Desember 2019

DOI: $10.34010 /$ agregasi.v7i2.2584

Available online at: https://ojs.unikom.ac.id/index.php/agregasi

\title{
EFEKTIVITAS PELAYANAN PROGRAM JAMINAN KESEHATAN DI DESA SIRNABAYA KECAMATAN TELUKJAMBE TIMUR KABUPATEN KARAWANG
}

\author{
Eka Yulyana \\ Program Studi Ilmu Pemerintahan, Universitas Singaperbangsa Karawang. \\ Jalan HS. Ronggowaluyo Teluk Jambe Timur, Kabupaten Karawang, \\ Jawa Barat, 41361 Indonesia. \\ * Korespondensi Penulis. E-mail: eka.yulyana@staff.unsika.ac.id , Telp: +6281524282929
}

\begin{abstract}
Abstrak
Masyarakat miskin di Desa Sirnabaya belum seluruhnya memperoleh kartu Jaminan Kesehatan Masyarakat. Masyarakat masih sulit untuk mendapatkan pelayan jaminan kesehatan, atas permasalahan tersebut peneliti tertarik untuk melakukan penelitian. Penelitian yang dilakukan menggunakan pendekatan penelitian campuran (mixed method). Strategi metode campuran yang digunakan dalam penelitian ini adalah urutan analisis kuantitatif dan kualitatif, tujuan strategi ini adalah untuk mengidentifikasikan komponen konsep (subkonsep) melalui analisis data kuantitatif dan kemudian mengumpulkan data kualitatif guna memperluas informasi yang tersedia. Pengambilan sampel dilakukan dengan berdasarkan teknik Disproportionate Stratified Random Sampling. Efektifitas pelayanan terutama dalam pelayanan jaminan kesehatan daerah (Jamkesda) dilihat dari adanya tanggung jawab, responsif dan komitmen sebagai aparat desa dalam efektivitas pelayanan jaminan kesehatan daerah (Jamkesda) masuk dalam kategori baik, efektivitas pelayanan termasuk dalam kategori baik akan tetapi beberapa sub variabel atau tolak ukur yang dinilai masyarakat masih belum optimal pada kenyataannya ada beberapa responden merasakan kesulitan dalam menghubungi aparat untuk mendapatkan pelayanan serta mendapatkan perlakuan yang tidak sama dalam pelayanan.
\end{abstract}

Kata Kunci: Efektivitas, Pelayanan, Jamkes, Desa

\section{THE ROLE OF BANDUNG WETAN SUB-DISTRICT IN EMPOWERING OF REGIONAL DEVELOPMENT INNOVATION PROGRAM (PIPPK)}

\begin{abstract}
The poor are not yet in Sirnabaya Village yet getting a card JKM. The community is still difficult to get health insurance servants, for these questions researchers are interested in conducting research. Research conducted using mixed research (mixed methods). The mixed method strategy used in this study is a sequence of quantitative and qualitative analysis, the purpose of this strategy is to identify the concept component (subconcept) through analyzing quantitative data and then collecting qualitative data to obtain available information. Sampling is done using the Disproportionate Stratified Random Sampling technique. Priority service effectiveness in the Regional Health Insurance service (Jamkesda) is seen from responsibility responsibility, responsiveness and commitment as village officials in regional health service needs (Jamkesda) included in the good category, service improvement according to the category either but in accordance with sub-variables or rejecting Measurement which is intended for the community is still not optimal in some of the respondents who have difficulty in contacting officers to get services and get assistance that is not the same in the service.
\end{abstract}

Keywords: effectiveness, service, health care insurance, village 


\section{PENDAHULUAN}

Kesehatan adalah hak setiap warga negara. Selain menjadi indikator tingkat kesejahteraan, kualitas kesehatan juga terkait dengan produktivitas masyarakat. Persoalan yang terjadi adalah bahwa kesehatan sering dianggap sebagai sesuatu yang mahal bagi sebagian orang. Sebagian diantara masyarakat bahkan terjebak pada pengobatan-pengobatan tradisional yang belum terbukti secara medis.

Terhadap kenyataan itu, pemerintah telah menggulirkan Program Jaminan Kesehatan Nasional disingkat Program JKN adalah suatu program Pemerintah dan Masyarakat/Rakyat dengan tujuan memberikan kepastian jaminan kesehatan yang menyeluruh bagi setiap rakyat Indonesia agar penduduk Indonesia dapat hidup sehat, produktif, dan sejahtera, yang terdiri dari program Jamkesmas (Jaminan Kesehatan Masyarakat) dan Jamkesda , yaitu bentuk belanja bantuan sosial yang diselenggarakan pemerintah pusat bersama pemerintah daerah propinsi dan kabupaten untuk pelayanan kesehatan bagi masyarakat miskin dan tidak mampu. Program ini diselenggarakan secara nasional dalam rangka mewujudkan pelayanan kesehatan yang menyeluruh.

Di Kabupaten Karawang, hal ini tertuang dalam Peraturan Bupati
Karawang Nomor 70 tahun 2012 tentang Petunjuk Teknis Jaminan Kesehatan Masyarakat Miskin (JPKMM) dan Jaminan Persalinan (Jampersal) Kabupaten Karawang tahun 2012. Program ini juga menyentuh penduduk Kabupaten Karawang. Namun pada kenyataannya tidak semua penduduk miskin bisa mendapatkan fasilitas ini, sehingga Pemerintah Kabupaten Karawang melengkapinya dengan program Jaminan Kesehatan Daerah (Jamkesda) yaitu bentuk pembiayaan pelayanan kesehatan yang diselenggarakan bersama antara Pemerintah Kabupaten Karawang dengan Pemerintah Propinsi Jawa Barat untuk pelayanan kesehatan bagi masyarakat miskin dan tidak mampu yang tidak terdaftar dalam kepesertaan program Jamkesmas.

Program Jamkesda ini dijalankan di Desa Sirnabaya Kecamatan Telukjambe Timur Kabupaten Karawang. Tetapi dalam pelaksanaannya masih banyak warga yang belum terdaftar dan sebagai penerima manfaat jaminan kesehatan. Masyarakat miskin belum di Desa Sirnabaya belum seluruhnya memperoleh kartu. Masyarakat masih sulit untuk mendapatkan pelayan jaminan kesehatan. Atas dasar permasalahan tersebut peneliti tertarik untuk meneliti serta menentukan judul dalam penelitian ini adalah "Efektivitas Program Jamkesda Di 


\section{Desa Sirnabaya Kecamatan}

Telukjambe Timur Kabupaten

Karawang". Rumusan Masalah dalam penelitian ini adalah: Bagaimana efektivitas pelayanan jaminan kesehatan di Desa Sirnabaya Kecamatan Telukjambe Timur Kabupaten Karawang?

\section{Tujuan}

Adapun tujuan yang ingin dicapai dalam penelitian adalah menganalisis dan mendeskripsikan Efektivitas pelayanan jaminan kesehatan daerah di Desa Sirnabaya, Kecamatan Telukjambe Timur, Kabupaten Karawang.

\section{Luaran Yang Diharapkan}

Pemerintah Desa dapat memberikan pelayanan yang prima kepada seluruh mayarakat penerima manfaat jaminan kesehatan.

\section{Kegunaan}

Diharapkan dapat memberikan masukan bagi pemerintah dalam hal peningkatan kualitas pelayanan kepada masyarakat dalam pelayanan jeminan kesehatan daerah (jamkesda) dengan penelitian ini, hasil penelitian ini dapat merekomendasikan kepada aparat mengenai kebutuhan masyarakat dalam hal pelayanan kesehatan.

Kesehatan adalah hak setiap warga negara. Selain menjadi indikator tingkat kesejahteraan, kualitas kesehatan juga terkait dengan produktivitas masyarakat.

Pemerintah telah menggulirkan program Jamkesmas (Jaminan Kesehatan Masyarakat), yaitu bentuk belanja bantuan sosial yang diselenggarakan pemerintah pusat bersama pemerintah daerah propinsi dan kabupaten untuk pelayanan kesehatan bagi masyarakat miskin dan tidak mampu. Program ini diselenggarakan secara nasional dalam rangka mewujudkan pelayanan kesehatan yang menyeluruh. Hal ini tertuang dalam Peraturan Bupati Karawang Nomor 70 tahun 2012 tentang Petunjuk Teknis Jaminan Kesehatan Masyarakat Miskin (JPKMM) dan Jaminan Persalinan (Jampersal) Kabupaten Karawang tahun 2012. Program ini juga menyentuh penduduk Kabupaten Karawang.

Pelayanan menurut Moenir (1995:17) yang mengutip pendapat Luthans dalam bukunya Manajemen pelayanan umum di Indonesia, yaitu "sebagai proses yang menunjuk kepada segala usaha yang dilakukan oleh salah satu pihak kepada pihak lain dalam rangka pencapaian tujuan tertentu".

Kegiatan pelayanan publik yang diselenggarakan pemerintah kepada masyarakat meliputi banyak hal yang menyangkut semua kebutuhan masyarakat. Hal ini sejalan dengan pendapat Pamudji dalam bukunya profesionalisme Aparatur negara 
dalam meningkatkan pelayanan publik, bahwa :

Jasa pelayananan pemerintah yaitu berbagai kegiatan yang bertujuan memenuhi kebutuhan masyarakat akan barang-barang dan jasa-jasa. Jenis pelayanan publik dalam arti jasa-jasa, yaitu seperti pelayanan kesehatan, pelayanan keluarga, pelayanan pendidikan, pelayanan haji, pelayanan, pencarian keadilan, dan lain-lain (Pamudji,1994:2122).

Untuk memberikan pelayanan publik yang baik atau memberikan kualitas pelayanan publik yang tinggi, aparat pemerintah harus memiliki tiga aspek yang diuraikan oleh Supriatna (1996:98) dalam bukunya Administrasi Birokrasi dan Pelayanan Publik, yaitu ;

a. Memiliki tanggung jawab yang tinggi selaku abdi negara dan abdi masyarakat.

b. Responsif terhadap masalah yang dihadapi masayarakat khususnya yang membutuhkan pelayanan masyarakat dalam arti luas.

c. Komitmen dan konsisten terhadap nilai standar moralitas dalam menjalankan kekuasaan pemerintahan.

Secara detail mengenai kerangka pikir ini dituangkan dalam model sebagai berikut :

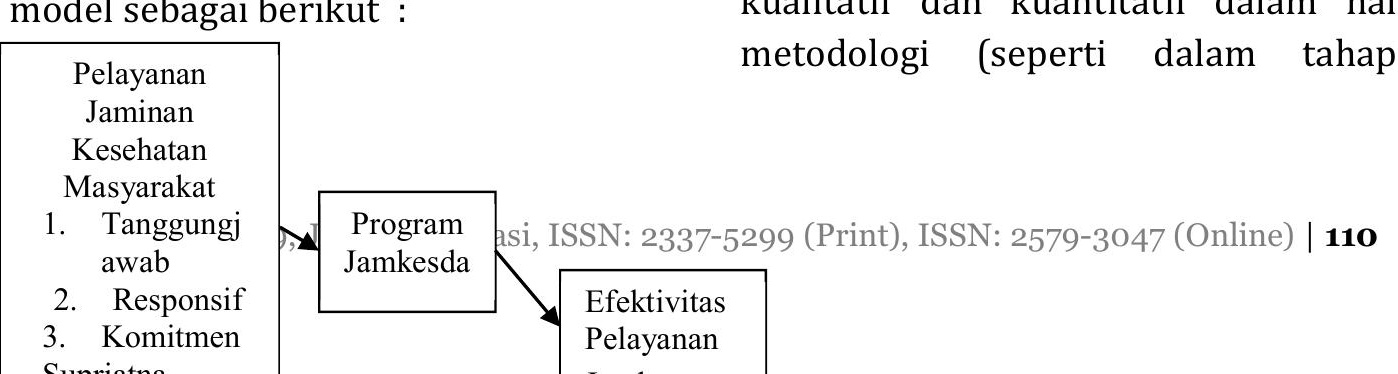

Gambar 1. Struktur Kerangka Pemikiran

\section{METODE}

Penelitian ini dilaksanakan di Desa Sirnabaya Kecamatan Telukjambe Timur Kabupaten Karawang Jawa Barat. Desa Sirnabaya terdiri dari 2 (dua) dusun yaitu Dusun I yang didalamnya terdapat Dusun Karajan, Dusun Pajaten, Dusun Saptamarga dan Dusun II, terdiri dari Sirnabaya Indah, Puri Krajan, dan Puri Telukjambe. Berdasarkan hal tersebut, dalam penelitian ini, peneliti berusaha untuk mengkaji pada pokok masalah mengenai efektivitas pelayanan jaminan kesehatan di Desa Sirnabaya Kecamatan Telukjambe Timur Kabupaten Karawang

\section{Jenis Penelitian}

Jenis penelitian yang dilakukan oleh penulis adalah lapangan (field research) penulis menggunakan jenis penelitian campuran (mixed methodology). Mixed Method adalah metode yang memadukan pendekatan kualitatif dan kuantitatif dalam hal metodologi (seperti dalam tahap 
DOI: $10.34010 /$ agregasi.v7i2.2584

pengumpulan data), dan kajian model campuran memadukan dua pendekatan dalam semua tahapan proses penelitian.

\section{Waktu dan Tempat Penelitian}

Penelitian ini dilaksanakan pada tahun 2013 di Desa Sirnabaya terdiri dari 2 (dua) dusun yaitu Dusun I yang didalamnya terdapat Dusun Karajan, Dusun Pajaten, Dusun Saptamarga dan Dusun II, terdiri dari Sirnabaya Indah, Puri Krajan, dan Puri Telukjambe.

\section{Target/Subjek Penelitian}

Tabel 1. Penentuan Sampel dari Penerima Jaminan kesehatan Daerah (Jamkesda) Desa Sirnabaya, Kecamatan Telukjambe Timur Kabupaten Karawang

\section{HASIL DAN PEMBAHASAN}

Efektivitas Pelayanan dilihat dari Tanggung Jawab

Dalam mengukur indikator tanggung jawab yang merupakan salah satu ukuran efektifitas pelayanan jaminan kesehatan daerah (jamkesda) di dasarkan pada tanggung jawab aparat desa dalam melaksanakan wewenang, tugas pokok dan fungsi sebagai pelayan masyarakat.

\section{Tanggung Jawab aparat desa terhadap wewenang yang diberikan}

Berdasarkan indikator tanggung jawab aparat desa terhadap wewenang yang dimiliki aparat desa sebagai pelayan masyarkat dapat dilihat hasil penelitan tersebut pada tabel di bawah

\begin{tabular}{|c|l|c|c|c|c|c|}
\hline NO & \multicolumn{1}{|c|}{ DUSUN } & $\begin{array}{c}\text { ukuran } \\
\text { Populasi }\end{array}$ & $\begin{array}{c}\text { \% dalam } \\
\text { Populasi }\end{array}$ & $\begin{array}{c}\text { Pecahan } \\
\text { Sampling }\end{array}$ & $\begin{array}{c}\mathbf{n} \\
\text { Sampling }\end{array}$ & $\begin{array}{c}\text { \% dal } \\
\text { Samp }\end{array}$ \\
\hline 1. & DUSUN I & & & & & \\
\hline & - -ARAJAN & 955 & 31 & 0,03 & 30 & 31 \\
\hline & - PAJATEN & 1.533 & 49 & 0,03 & 48 & 49 \\
\hline & - SAPTAMARGA & 295 & 9 & 0,03 & 9 & 9 \\
\hline 2. & DUSUN II & & & & & \\
\hline & - SIRNABAYA INDAH & 88 & 3 & 0,03 & 3 & 3 \\
\hline & - PURI KRAJAN & 188 & 6 & 0,03 & 6 & 6 \\
\hline & - PURI TELUKJAMBE & 59 & 2 & 0,03 & 2 & 2 \\
\hline & & & & & & \\
\hline & J U M L A H & $\mathbf{3 . 1 1 8}$ & $\mathbf{1 0 0}$ & & $\mathbf{9 7}$ & $\mathbf{1 0 0}$ \\
\hline
\end{tabular}

Sumber: olahan peneliti, 2013

Keterangan:

1. Jumlah Sampel 97

2. Pecahan Sampling Sampel/Populasi $=97 / 3118=0,03$

3. Setiap Strata diwakili dalam sampel proporsinya dalam populasi

4. Pecahan sampling x ukuran Populasi = sampel

abel 2. Jawaban Responden mengenai tanggung jawab terhadap wewenang parat desa sebagai pelayan masyarakat

\begin{tabular}{|c|c|c|c|c|c|}
\hline \begin{tabular}{c|l}
6 & \\
2 & Alternatif Jawaban \\
\end{tabular} & $\mathrm{n}$ & skor & xi & $\overline{\mathrm{X}}$ & $\%$ \\
\hline asalf gat bertanggungjawab & 1 & 5 & 5 & & 1,03 \\
\hline bertanggungiawab & 92 & 4 & 368 & & 94,85 \\
\hline Ragu-ragu & 4 & 3 & 12 & & 4,12 \\
\hline Kurang bertanggungawab & 0 & 2 & 0 & & 0,00 \\
\hline Tidak bertanggungiawab & 0 & 1 & 0 & & 0,00 \\
\hline Jumlah & 97 & & 385 & 3,97 & 100,00 \\
\hline
\end{tabular}

Sumber: Penelitian, 2014

Berdasarkan tabel tersebut di atas mayoritas responden menjawab bahwa aparat desa telah "bertanggung jawab" terhadap wewenang yang diberikan sebagai pelayan masyarakat 
dalam berbagai urusan yang berkaitan dengan pelayanan program Jaminan Kesehatan Daerah (Jamkesda). Hal ini disebabkan mayoritas responden merasa puas dengan pelayanan aparat desa. Hal ini terlihat pada saat ada masyarakat penerima program jamkesda mengalami sakit dan perlu dirujuk ke rumah sakit maka dengan rasa tanggungjawab aparat desa memberikan bantuan transportasi dengan mobil desa yang telah disediakan. Sedangkan 4 orang responden menjawab "ragu-ragu" mengenai aparat desa dalam mengemban wewenang yang diberikannya sebagai pelayan masyarakat. Hal ini karena responden merasakan tanggung jawab dari aparat desa kurang optimal dari pelayanan yang diberikan. Sebanyak 1 orang responden menjawab "sangat bertanggungjawab" berkaitan dengan tanggungjawab aparat desa terhadap wewenang yang diberikan sebagai pelayan masyarakat. Hal ini dikarenakan responden ini merasa pelayanan yang diterima berkaitan dengan program jaminan kesehatan daerah (Jamkesda) sangat puas.

\section{Pelaksanaan tugas pokok dan fungsi aparat desa}

Indikator berikutnya berkaitan dengan tanggung jawab yaitu, perihal pelaksanaan tugas pokok dan fungsi aparat desa dalam penyelenggaraan pemerintahan desa berkaitan dengan pelayanan jaminan kesehatan daerah (jamkesda). Hasil penelitian dan pembahasannya dapat dilihat pada tabel 3. di bawah ini:

Tabel 3. Jawaban Responden mengenai pelaksanaan tugas pokok dan fungsi aparat desa sebagai pelayan masyarakat dalam program Jamkesda

\begin{tabular}{|l|c|c|c|c|c|}
\hline \multicolumn{1}{|c|}{ Alternatif Jawaban } & $\mathbf{n}$ & skor & $\mathbf{x i}$ & $\overline{\mathrm{X}}$ & $\mathbf{\%}$ \\
\hline Sangat melaksanakan & 0 & 5 & 0 & & 0,00 \\
\hline melaksanakan & 91 & 4 & 364 & & 93,81 \\
\hline Ragu-ragu & 6 & 3 & 18 & & 6,19 \\
\hline Kurang melaksanakan & 0 & 2 & 0 & & 0,00 \\
\hline Tidak melaksanakan & 0 & 1 & 0 & & 0,00 \\
\hline Jumlah & 97 & & 382 & 3,94 & 100,00 \\
\hline
\end{tabular}

Sumber: Penelitian, 2014

Dapat dilihat pada tabel di atas bahwa mayoritas responden sebanyak 91 orang responden menjawab "melaksanakan" tugas pokok dan fungsi aparat desa dalam hal pelayanan yang berkaitan dengan program jaminan kesehatan daerah (Jamkesda). Hal ini disebabkan responden sangat menghargai kinerja para aparat desa dalam membantu masyarakat menyelesaikan urusannya baik bantuan informasi maupun fasilitas. Sedangkan sebanyak 6 orang responden menjawab "ragu-ragu" hal ini karena responden merasa bahwa aparat desa telah melaksanakan sebagaimana mestinya tugas pokok dan fungsinya dalam hal pelayanan kepada masyarakat. 
Jawaban responden terhadap indikator-indikator tanggung jawab yang berkaitan dengan wewenang, tugas pokok dan fungsi aparat desa sebagai pelayan masyarakat dalam hal penyelesaian berbagai urusan yang berkaitan dengan pelayanan jaminana kesehatan daerah (Jamkesda) dapat diakumulasikan pada tabel 4. di bawah ini:

Tabel 4. Akumulasi Jawaban responden terhadap indikator tanggung jawab.

\begin{tabular}{|l|c|c|c|c|c|}
\hline \multicolumn{1}{|c|}{ Alternatif Jawaban } & $\mathbf{n}$ & $\mathbf{s k o r}$ & $\mathbf{x i}$ & $\overline{\mathbf{X}}$ & $\mathbf{\%}$ \\
\hline sangat baik & 1 & 5 & 5 & & 0,52 \\
\hline baik & 183 & 4 & 732 & & 94,33 \\
\hline Ragu-ragu & 10 & 3 & 30 & & 5,15 \\
\hline kurang & 0 & 2 & 0 & & 0,00 \\
\hline sangat kurang & 0 & 1 & 0 & & 0,00 \\
\hline Jumlah & 194 & & 767 & 3,95 & 100,00 \\
\hline
\end{tabular}

Sumber: penelitian, 2013

Hasil jawaban responden terhadap indikator tanggung jawab yang berkaitan dengan wewenang, tugas pokok dan fungsi aparat desa sebagai pelayan masyarakat dalam hal penyelesaian berbagai urusan yang berkaitan dengan pelayanan jaminan kesehatan daerah (jamkesda) dapat menunjukkan bahwa skor 767. Dari 2 pertanyaan yang diajukan kepada 97 responden diperoleh jawaban yaitu $2 \mathrm{x}$ $97=194$, maka nilai rata-rata terhadap indikator tanggung jawab adalah 767: $194=3$,95. Berdasarkan interval skor, maka skor 3,95 berada pada kategori "baik". Dengan demikian tanggung jawab yang diberikan aparat desa sebagai pelayan masyarakat berkaitan dengan penyelesaian berbagai urusan yang berkaitan dengan program jaminan kesehatan masyarakat harus terus ditingkatkan, dan terus mengedepankan kepuasan masyrakat sehingga dapat menunjang efektifitas pelayanan jaminan kesehatan daerah (Jamkesda).

\section{Efektivitas Pelayanan dilihat dari Responsif}

Dalam mengukur indikator indikator responsif, yang merupakan salah satu ukuran kualitas pelayanan publik dalam pelayanan jaminan kesehatan daerah (Jamkesda) didasarkan pada tolak ukur:

\section{Kemampuan aparatur membantu masyarakat mendapatkan pelayanan mudah dan tidak berbelit}

Berdasarkan tolak ukur kemampuan aparatur membantu masyarakat mendapatkan pelayanan yang mudah dan tidak berbelit dalam pelayanan jaminan kesehatan daerah (Jamkesda). Adapun hasil penelitian dan pembahasannya dapat dilihat pada tabel 5. di bawah ini:

Tabel 5. Jawaban Responden mengenai Kemampuan aparatur membantu masyarakat mendapatkan pelayanan mudah dan tidak berbelit 
DOI: 10.34010/agregasi.v7i2.2584

\begin{tabular}{|l|c|c|c|c|c|}
\hline Altematif Jawaban & $\mathbf{n}$ & skor & $\mathbf{x i}$ & $\overline{\mathrm{X}}$ & $\mathbf{\%}$ \\
\hline Sangat baik & 0 & 5 & 0 & & 0,00 \\
\hline Baik & 45 & 4 & 180 & & 46,39 \\
\hline Ragu-ragu & 52 & 3 & 156 & & 53,01 \\
\hline Kurang & 0 & 2 & 0 & & 0,00 \\
\hline Sangat kurang & 0 & 1 & 0 & & 0,00 \\
\hline Jumlah & 97 & & 336 & 3,46 & 100,00 \\
\hline
\end{tabular}

Sumber: Penelitian, 2013

Pada tabel di atas terlihat sebanyak 52 orang responden menjawab "cukup baik" dengan kemampuan aparatur dalam membantu masyarakat untuk mendapatkan pelayanan yang mudah dan tidak berbelit. Hal ini dikarenakan responden merasa mendapatkan bantuan dalam pengurusan dokumendokumen yang berkaitan dengan prosedur pelayanan jaminan kesehatan daerah (jamkesda), hal ini diakui responden bahwa pengurusan dokumen-dokumen yang berkaitan dengan pelayanan jaminan kesehatan daerah (Jamkesda) memerlukan orangorang yang terbiasa mengurusnya agar terasa mudah. Sedangkan sebanyak 45 orang responden menjawab "baik" hal ini disebabkan responden mendapat pelayanan yang baik dan merasakan pelayanan yang mudah dalam pengurusan dokumen-dokumen.

\section{Kemampuan aparatur dalam membantu masyarakat yang mengalami kesulitan dalam}

pelayanan jaminan kesehatan daerah (Jamkesda)

Kemampuan aparatur dalam membantu masyarakat yang mengalami kesulitan dalam pelayanan jaminan kesehatan daerah (jamkesda) lebih lanjut dapat dilihat hasil penelitan dan pembahasan pada tabel 6 di bawah ini:

Tabel 6. Jawaban Responden mengenai kemampuan aparatur dalam membantu masyarakat yang mengalami kesulitan

\begin{tabular}{|l|c|c|c|c|c|}
\hline \multicolumn{1}{|c|}{ Alternatif Jawaban } & $\mathbf{n}$ & $\mathbf{~}$ & $\mathbf{x i}$ & $\overline{\mathrm{X}}$ & $\mathbf{\%}$ \\
\hline Sangat Membantu & 1 & 5 & 5 & & 1,03 \\
\hline Membantu & 45 & 4 & 180 & & 46,39 \\
\hline Ragu-ragu & 51 & 3 & 153 & & 52,58 \\
\hline Kurang membantu & 0 & 2 & 0 & & 0,00 \\
\hline Tidak membantu & 0 & 1 & 0 & & 0,00 \\
\hline Jumlah & 97 & & 338 & 3,48 & 100,00 \\
\hline
\end{tabular}

Sumber: Penelitian, 2013

Pada tabel di atas dapat dilihat bahwa sebanyak 51 orang responden menjawab "ragu-ragu" mengenai kemampuan aparatur untuk menghadapi kesulitan dalam pelayanan jaminanan kesehatan daerah (Jamkesda). Responden mengakui bahwa selama ini aparatur segera membantu apabila terdapat ketidaktahuan persyaratan untuk melengkapi dokumen mendapatkan pelayanan jaminan kesehatan daerah (Jamkesda). Sebanyak 45 orang responden menjawab bahwa aparatur "membantu" dengan cepat terhadap masyarakat yang mendapatkan kesulitan dalam pelayanan jaminan 
kesehatan daerah. Hal ini diakui responden bahwa daya tanggap aparatur baik sehingga berbagai kesulitan yang dihadapi masyarakat dapat segera di atasi. 1 orang menjawab "sangat membantu" hal ini disebabkan bahwa daya tanggap aparatur dianggap sangat baik dan cepat, responden merasa sangat bersyukur dengan bantuan yang diberikan oleh aparatur sehingga halhal yang tidak diinginkan responden tidak terjadi.

\section{Kreatifitas aparatur melayani masyarakat dalam pelayanan program jaminan kesehatan Daerah (Jamkesda)}

Kreatifitas aparatur sangat diperlukan untuk menunjang pelayanan yang maksimal, Jawaban responden berkaitan dengan kreatifitas aparatur melayani masyarakat dalam pelayanan program jaminan kesehatan daerah (Jamkesda) dapat dilihat pada tabel 7. di bawah ini:

Tabel 7. Jawaban Responden mengenai kreatifitas aparatur melayani masyarakat dalam Program Jaminan Kesehatan Daerah (Jamkesda)

\begin{tabular}{|l|c|c|c|c|c|}
\hline \multicolumn{1}{|c|}{ Alternatif Jawaban } & $\mathbf{n}$ & skor & $\mathbf{x i}$ & $\overline{\mathbf{X}}$ & $\mathbf{\%}$ \\
\hline Sangat baik & 0 & 5 & 0 & & 0,00 \\
\hline Baik & 67 & 4 & 268 & & 69,07 \\
\hline Ragu-ragu & 30 & 3 & 90 & & 30,93 \\
\hline Kurang baik & 0 & 2 & 0 & & 0,00 \\
\hline Tidak baik & 0 & 1 & 0 & & 0,00 \\
\hline Jumlah & 97 & & 358 & 3,69 & 100,00 \\
\hline
\end{tabular}

Sumber: Penelitian, 2013
Berdasarkan pada tabel di atas dapat di lihat sebanyak 67 orang responden menjawab "baik" mengenai kreatifitas aparatur dalam melayani masyarakat dalam pelayanan jaminan kesehatan daerah. Kreatifitas aparatur di nilai baik, karena responden merasa apabila ada informasi yang diterima aparatur berkaitan dengan kejadian yang menimpa salah satu penerima program jaminan kesehatan daerah (jamkesda) maka aparatur akan menyambanginya untuk dapat mendapatkan pengobatan yang layak. Sebanyak 30 orang respoden menjawab "cukup baik" berkaitan dengan kreatifitas aparatur, hal ini di sebabkan karena responden beranggapan bahwa pelayanan yang diterimanya selama ini cukup baik. Akumulasi jawaban responden terhadap indikator responsif, dapat dilihat pada tabel 8. di bawah ini:

Tabel 8. Akumulasi Jawaban

Responden terhadap Indikator Responsif

\begin{tabular}{|l|c|c|c|c|c|}
\hline \multicolumn{1}{|c|}{ Alternatif Jawaban } & $\mathbf{n}$ & $\mathbf{s k o r}$ & $\mathbf{x i}$ & $\overline{\mathrm{X}}$ & $\mathbf{\%}$ \\
\hline sangat baik & 1 & 5 & 5 & & 0,34 \\
\hline Baik & 157 & 4 & 628 & & 53,95 \\
\hline Ragu-ragu & 133 & 3 & 399 & & 45,70 \\
\hline kurang & 0 & 2 & 0 & & 0,00 \\
\hline sangat kurang & 0 & 1 & 0 & & 0,00 \\
\hline Jumlah & 291 & & 1032 & 3,55 & 100,00 \\
\hline
\end{tabular}

Sumber: Penelitian, 2013

Berdasarkan tabel di atas, dapat dikatakan bahwa penilaian terhadap 
responsif yang meliputi: kemampuan aparatur membantu masyarakat mendapatkan pelayanan yang mudah dan tidak berbelit dalam pelayanan program jaminan kesehatan daerah (jamkesda), kemampuan aparatur membantu masyarakat yang mengalami kesulitan dalam pelayanan Jaminan Kesehatan Daerah (Jamkesda), dan kreatifitas aparatur dalam melayani masyarakat dalam program Jamkesda. Menunjukkan skor 1.032 diperoleh dari 3 pertanyaan yang diajukan kepada 97 responden. Maka diperoleh total jawaban $3 \times 97=291$.

Berdasarkan interval skor yang diperoleh dari hasil skor tertinggi dikurangi dengan skor terendah dibagi dengan jumlah banyaknya pilihan jawaban. Dengan demikian diperoleh interval untuk setiap kategori jawaban. Pengkategorian tersebut digunakan untuk menganalisis setiap sub indikator atau tolak ukur dari variabel bebas dan variabel terikat dengan mencari rata-rata. Maka nilai rata-rata terhadap inikator responsif pelayanan jaminan kesehatan daerah (Jamkesda) adalah 1.032:291 = 3,55.

Berdasarkan interval skor, maka skor 3,55 dapat ditafsirkan nilai ratarata jawaban responden mengenai responsif dalam pelayanan jaminan kesehatan daeraeh (Jamkesda) berada pada kategori cukup.

Responsif dapat diartikan keinginan dari aparatur desa untuk membantu penerima jaminan kesehatan daerah (Jamkesda) seperti merespon kesulitan-kesulitan yang dialami masyarakat dalam pengurusan dokumen-dokumen mengenai Jamkesda serta memudahkan akses pelayanan. Responsif aparatur desa berdasarkan jawaban responden tersebut masuk kedalam kategori cukup baik. Ini terlihat dari cukup baik aparatur desa dalam membantu penerima jamkesda untuk menyelesaikan berbagai urusan dalam pelayanan jaminan kesehatan daerah.

\section{Efektivitas Pelayanan dilihat dari Komitmen}

a. Pelayanan yang sopan dan ramah dari aparatur desa

Sopan dan ramah aparatur desa dalam melayani masyarakat dianjurkan dalam rangka memberikan kepuasan pelayanan. Adapun hasil penelitian dan pembahasannya adalah:

Tabel 9. Jawaban Responden mengenai Pelayanan yang ramah dan sopan dari aparatur desa dalam pelayanan Jaminan Kesehatan Daerah (Jamkesda)

\begin{tabular}{|l|c|c|c|c|c|}
\hline \multicolumn{1}{|c|}{ Alternatif Jawaban } & $\mathbf{n}$ & skor & $\mathbf{x i}$ & $\overline{\mathrm{X}}$ & $\mathbf{\%}$ \\
\hline Sangat baik & 2 & 5 & 10 & & 2,06 \\
\hline Baik & 89 & 4 & 356 & & 91,75 \\
\hline Ragu-ragu & 5 & 3 & 15 & & 5,15 \\
\hline Kurang baik & 0 & 2 & 0 & & 0,00 \\
\hline Tidak baik & 1 & 1 & 1 & 3,94 & 1,03 \\
\hline Jumlah & 97 & & 382 & & 100,00 \\
\hline
\end{tabular}

Sumber: Penelitian, 2013 
Berdasarkan tabel tersebut, sebagian besar responden yaitu sebanyak 89 orang responden atau sekitar 91,75\% memberikan penilaian baik terhadap keramahan dan kesopanan dalam pelayanan jaminan kesehatan daerah (Jamkesda) dan 2 orang responden menjawab sangat baik, 5 orang responden menjawab cukup baik. Sedangkan 1 orang responden menjawab tidak baik.

Data di atas menunjukkan bahwa keramahan dan kesopanan aparatur dalam pelayanan jaminan kesehatan daerah (Jamkesda) sudah baik. Sikap aparatur desa pada umumnya yang bertugas melayani penerima jaminan kesehatan sudah bersikap ramah dan sopan.

b. Kemudahan pelayanan bagi penerima jaminan kesehatan daerah untuk menghubungi aparatur dalam mendapatkan pelayanan.

Adapun hasil dan penelitian berkaitan dengan tolak ukur kemudahan pelayanan bagi penerima jamkesda dalam menghubungi aparatur dalam mendapatkan pelayanan dapat dilihat pada tabel 10 . di bawah ini:

Tabel 10. Jawaban Responden mengenai kemudahan pelayanan bagi penerima Jamkesda untuk menghubungi aparatur dalam mendapatkan pelayanan

\begin{tabular}{|l|c|c|c|c|c|}
\hline \multicolumn{1}{|c|}{ Alternatif Jawaban } & n & skor & $\mathbf{x i}$ & $\overline{\mathbf{X}}$ & $\mathbf{\%}$ \\
\hline Sangat mudah & 0 & 5 & 0 & & 0,00 \\
\hline Mudah & 88 & 4 & 352 & & 90,72 \\
\hline Ragu-ragu & 9 & 3 & 27 & & 9,28 \\
\hline Sullit & 0 & 2 & 0 & & 0,00 \\
\hline Sangat sulit & 0 & 1 & 0 & & 0,00 \\
\hline Jumlah & 97 & & 379 & 3,91 & 100,00 \\
\hline
\end{tabular}

Sumber: Penelitian, 2013

Berdasarkan tabel di atas, sebagian besar responden yaitu sebanyak 88 orang responden atau sebesar 90,72\% responden menjawab mudah dalam menghubungi aparatur dalam mendapatkan pelayanan. Dan sebannyak 9 orang responden menjawab cukup mudah.

Data di atas menunjukkan bahwa penerima jaminan kesehatan daerah (Jamkesda) mendapatkan kemudahan untuk menghubungi aparatur apabila hendak melakukan pelayanan. Akan tetapi hal lain yang peneliti amati kadang aparatur tidak berada di tempat untuk mengadakan pelayanan terhadap masyarakat. Namun hal itu bukan menjadi kendala, karena selain pelayanan di adakan di kantor desa kadang juga bisa dilakukan di rumah aparatur ketika di luar jam kerja. Seperti di kemukakan salah satu aparat yang peneliti wawancara bahwa aparat berusaha memberikan kemudahan untuk menghubunginya kapanpun waktunya.

\section{Perlakuan yang sama oleh dalam hal pelayanan jaminan kesehatan daerah oleh aparatur desa.}


Penerima jaminan kesehatan daerah mendapatkan pelayanan yang sama (tanpa membed-bedakan status penerima jaminan kesehatan daerah (Jamkesda)) oleh aparatur desa, hal ini dapat dilihat pada tabel di bawah ini:

Tabel 11. Jawaban Responden mengenai perlakuan yang sama dalam hal pelayanan jaminan kesehatan oleh aparatur

\begin{tabular}{|l|c|c|c|c|c|}
\hline \multicolumn{1}{|c|}{ Alternatif Jawaban } & $\mathbf{n}$ & skor & $\mathbf{x i}$ & $\overline{\mathbf{X}}$ & $\mathbf{\%}$ \\
\hline Sangat sama & 0 & 5 & 0 & & 0,00 \\
\hline sama & 73 & 4 & 292 & & 75,26 \\
\hline Ragu-ragu & 18 & 3 & 54 & & 18,56 \\
\hline Kurang sama & 3 & 2 & 6 & & 3,09 \\
\hline Tidak sama & 3 & 1 & 3 & & 3,09 \\
\hline Jumlah & 97 & & 355 & 3,66 & 100,00 \\
\hline
\end{tabular}

Sumber: Penelitian 2013

Berdasarkan tabel tersebut, sebagian besar responden yaitu sebanyak 73 responden atau sekitar $75,26 \%$ merasa mendapatkan perlakuan yang sama dari aparatur desa, 18 orang responden menilai diberikan cukup sama, 3 orang responden menjawab kurang sama dan 3 orang responden lagi menjawab tidak sama.

Dari jawaban responden tersebut di atas, nampak sebagian respon merasa mendapatkan perlakuan yang sama tanpa dibedabedakan statusnya. Namun beberapa responden menilai ada ke tidak samaan pelayanan oleh aparat hal ini disampaikan responden karena dipengaruhi oleh hubungan dekat dengan sang aparat.

Akumulasi jawaban responden terhadap indikator Komitmen dapat dilihat pada tebel 12 di bawah ini:

Tabel 12. Akumulasi Jawaban Responden terhadap indikator Komitmen

\begin{tabular}{|l|c|c|c|c|c|}
\hline \multicolumn{1}{|c|}{ Alternatif Jawaban } & $\mathbf{f i}$ & $\mathbf{x i}$ & $\mathbf{f i x i}$ & $\overline{\mathrm{X}}$ & $\mathbf{\%}$ \\
\hline sangat baik & 2 & 5 & 10 & & 0,69 \\
\hline baik" & 250 & 4 & 1000 & & 85,91 \\
\hline cukup & 32 & 3 & 96 & & 11,00 \\
\hline kurang & 3 & 2 & 6 & & 1,03 \\
\hline sangat kurang & 4 & 1 & 4 & & 1,37 \\
\hline Jumlah & 291 & & 1116 & 3,84 & 100,00 \\
\hline
\end{tabular}

Sumber : Penelitian, 2013

Berdasarkan tabel di atas dapat di berikan penilaian terhadap komitmen para aparat desa dalam melayani penerima jaminan kesehatan yang meliputi: pelayanan yang ramah dan sopan dari aparat, kemudahan yang diberikan dalam pelayanan dan perlakuan yang sama yang diberikan aparat desa dalam memberikan pelayanan jaminan kesehatan daerah diperoleh skor 1.116 dengan 3 pertanyaan yang diajukan kepada 97 orang responden maka diperoleh total jawaban 3 × $97=291$.

Maka nilai rata-rata terhadap indikator responsif pelayanan jaminan kesehatan daerah (Jamkesda) adalah $1.116: 291=3,84$. Berdasarkan interval skor maka skor 3,83 dapat ditafsirkan nilai rata-rata jawaban responden mengenai komitmen aparat dalam 
pelayanan jaminan kesehatan daeraeh (Jamkesda) berada pada kategori baik. Komitmen merupakan suatu niat baik yang dimiliki oleh seorang aparat sebagai pelayan masyarakat demi untuk kepuasan masyarakat, namun tetap melaksanakan pelayanan dengan penuh tanggung jawab dan tetap menjaga etika sebagai aparat yang baik. Akumulasi jawaban responden terhadap variabel terikat (efektifitas pelayanan jaminan kesehatan daerah (jamkesda) dapat dilihat pada tabel 13 di bawah ini:

Tabel 14. Akumulasi jawaban responden terhadap efektifitas pelayanan Jaminan Kesehatan.

\begin{tabular}{|c|c|c|c|c|c|c|}
\hline \multirow{2}{*}{$\mathbf{x i}$} & \multicolumn{7}{|c|}{ Responden } \\
\cline { 2 - 7 } & Y1 & Y2 & Y3 & fi & \% & fi.xi \\
\hline 5 & 1 & 1 & 2 & 4 & 0,52 & 20 \\
\hline 4 & 183 & 157 & 250 & 590 & 76,03 & 2.360 \\
\hline 3 & 10 & 133 & 32 & 175 & 22,55 & 525 \\
\hline 2 & 0 & 0 & 3 & 3 & 0,39 & 6 \\
\hline 1 & 0 & 0 & 4 & 4 & 0,52 & 4 \\
\hline Jumlah & 194 & 291 & 291 & 776 & 100,00 & 2.915 \\
\hline
\end{tabular}

Sumber: Penelitian, 2013

Berdasarkan tiga subvariabel efektifitas pelayanan jaminan kesehatan daerah (Jamkesda) sebagai variabel terikat disusun delapan pertanyaan yang bentuknya tertutup yang diajukan kepada 97 orang responden diperoleh total jawaban yaitu 8 × $97=776$, dari jawaban responden tersebut dapat diperoleh jumlah skor sebesar 2.915 dengan demikian nilai rata-rata jawaban responden adalah $2.915: 776=3,75$. Berdasarkan interval skor nilai skor 3,75 berada pada kategori baik.

Kecenderungan jawaban responden tersebut menunjukkan bahwa kualitas pelayanan jaminan kesehatan daerah (Jamkesda) yang diberikan aparatur melalui sikap tanggung jawab, responsif dan komitmen secara umum sudah dalam kategori baik dan harus dilakukan dan ditingkatkan pelaksanaannya. Hal ini tentunya sesuai dengan makna pelayanan yaitu memenuhi kepentingan masyarakat yang membutuhkan pelayanan dengan memprioritas kepuasan masyarakat. Seperti dikemukakan moenir bahwa apabila kepuasan masyarakat dapat dipenuhi maka dampak kepuasan masyarakat tersebut dapat dilihat pada:

i. Masyarakat sangat menghargai (respect) kepada korps pegawai yang bertugas di bidang pelayanan umum.

ii. Masyarakat terdorong mematuhi aturan dengan penuh kesadaran tanpa prasangka buruk

iii. Ada rasa bangga pada masyarakat atas karya korps pegawai di bidang layanan umum

iv. Kelambatan-kelambatan yang biasa ditemui dapat dihindarkan dan ditiadakan

v. Karena adanya kelancaran di bidagn pelayanan umum gairah 
usaha dan inisiatif masyarakat akan meningkat. (moenir, 2010: 45)

Efektivitas pelayanan publik berhubungan dengan pelayanan yang sistematis dan komprehensif yang dikenal dengan konsep pelayanan prima. Melalui kualitas pelayanan yang baik yang dilakukan oleh aparat desa maka pelayanan dapat berjalan dengan semestinya yang akan menimbulkan rasa puas sehingga perasaan resah yang timbul sebelum menerima pelayanan dapat hilang dengan seketika. Sehingga dengan demikian pelayanan yang efektif dapat terlaksana.

Berdasarkan analisa terhadap efektivitas pelayanan jaminan kesehatan daerah (Jamkesda), Indikator pelayanan dapat meningkatkan efektivitas pelayanan yang diberikan aparatur desa kepada masyarakat atau penerima Jamkesda khususnya dalam hal pelayanan Jaminan Kesehatan Daerah(Jamkesda) di Desa Sirnabaya, Kecamatan Telukjambe Timur Kabupaten Karawang. Berdasarkan perhitungan jawaban responden bahwa efektifitas pelayanan jaminan kesehatan daerah (Jamkesda) pada kategori baik.

Dengan kategori indikator: kritik, Tanggung jawab, dan Komitmen pada kategori baik; indikator koreksi dan responsif pada kategori cukup; dan indikator ide baru pada kategori kurang. Berdasarkan observasi peneliti, terlihat bahwa kategori jawaban responden lebih banyak kepada kategori baik dan cukup baik, tetapi bila dilihat pada kenyataan yang ada, seharusnya responden memilih jawaban rendah.

\section{SIMPULAN DAN SARAN}

\section{Simpulan}

Setelah peneliti melakukan penelitian dan pengamatan serta pengumpulan data-data serta hasil analisis mengenai efektifitas pelayanan jaminan kesehatan daerah (Jamkesda) di Desa Sirnabaya Kecamatan Telukjambe Timur Kabupaten Karawang, maka peneliti berkesimpulan bahwa:

Efektifitas pelayanan terutama dalam pelayanan jaminan kesehatan daerah (Jamkesda) dilihat dari adanya tanggung jawab, responsif dan komitmen sebagai aparat desa dalam efektifitas pelayanan jaminan kesehatan daerah (Jamkesda) masuk dalam kategori baik, walaupun efektivitas pelayanan termasuk dalam kategori baik akan tetapi beberapa sub variabel atau tolak ukur yang dinilai masyarakat masih belum optimal pada kenyataannya ada beberapa responden merasakan kesulitan dalam menghubungi aparat untuk mendapatkan pelayanan serta mendapatkan perlakuan yang tidak sama dalam pelayanan. 


\section{Saran}

Berdasarkan uraian kesimpulan di atas, mengenai pengaruh pengawasan masyarakat terhadap efektifitas pelayanan jaminan kesehatan daerah (Jamkesda) di Desa Sirnabaya, Kecamatan Telukjambe Timur, Karawang peneliti mengajukan saran-saran yang kiranya dapat meningkatkan kemampuan dalammemberikan pelayanan jaminan kesehatan daerah (Jamkesda), sebagai berikut:

1. Dalam upaya peningkatan efektifitas pelayanan dalam program Jaminan kesehatan Daerah (Jamkesda) peningkatan penyebaran informasi mengenai bagaimana prosedur pelayanan jaminan kesehatan daerah (Jamkesda) saat ini Jamkesmas di konversi Ke BPJS.

2. Berkaitan dengan pelayanan publik yang diberikan oleh pihak Desa Sirnabaya, memfasilitasi seluruh warga untuk memperoleh Jaminan Kesehatan.

\section{DAFTAR PUSTAKA}

Afiffudin, S. Ag., M.Si. (2010). Pengantar Administrasi Pembangunan. Bandung: Alfabeta

Handayaningrat, Soewarno. (1990). Pengantar Studi Ilmu Adminisstrasi dan Manajemen. Jakarta: CV Haji Masagung

Hasibuan, Malayu SP. (2001). Manajemen Dasar, Pengertian, dan Masalah. Jakarta: PT Bumi Aksara.

Kunarjo, (2002). Perencanaan dan Pengendalian Program Pembangunan. Jakarta: UI-Press

Lubis, Ibrahim. (1985). Pengendalian dan Pengawasan Proyek dalam Manajemen. Jakarta: Ghalia Indonesia

Lukman, Sampara. (1999). Manajemen Kualitas Pelayanan. Jakarta: Erlangga.

Mangkunegara, Anwar Prabu. (2011). Perencanaan dan Pengembangan Sumber Daya Manusia. Bandung: PT Refika Aditama

Moenir. (1995). Manajemen Pelayanan Publik di Indonesia. Jakarta: Bina Rupa Aksara

Moenir. (2010). Manajemen Pelayanan Publik di Indonesia. Jakarta: Bina Rupa Aksara

Napitupulu, Paimin. (2007). Pelayanan Publik dan Customer Satisfaction. Bandung: PT Alumni

Nawawi, Hadari. (1993). Pengawasan Melekat di Lingkungan Aparatur Pemerintah. Jakarta: Penerbit Erlangga

Nurcholis, Hanif dkk. (2009). Pedoman Pengembangan Perencanaan Pembangunan Perencanaan Partisipatif Pemerintahan Daerah. Jakarta: Grasindo

Poerwadarminta, WJS. (2006). Kamus Umum Bahasa Indonesia. Jakarta : Balai Pustaka

Rasyid, Ryaas. (1997). Pemerintahan Daerah. Jakarta: Bumi Aksara.

Riduan. (2002). Rumus dan Data dalam Aplikasi Statistika. Bandung: Alfabeta. 
Siagian, Sondang P. (1981). Filsafat Administrasis. Jakarta: PT. Toko Gunung Agung.

Singarimbun, Masri. (1995). Metode Penelitian Survai. Jakarta: PT Pustaka LP3ES Indonesia

Sukarna. (1990).

Social Control/Kontrol Masyarakat. Bandung: Citra Aditya Bakti

Supriatna, Tjahja. (1996). Administrasi Birokrasi dan Pelayanan Publik. Jakarta: Nimas Ultima

Sugiyono. (1998). Metode Penelitian Administrasi. Bandung: Alfabeta.

--------. (2011). Metode Penelitian Kuantitatif, kualitatif dan $R \& D$. Bandung : Alfabeta

\section{PROFIL SINGKAT}

Eka Yulyana, lahir di Kota Pangkal Perjuangan Karawang, 26 Juli 1981. Masa kecil sampai saat ini dihabiskan mengabdi di tengah masyarakat Karawang. Semenjak SD sudah terlihat bakat seni dan olahraga, sewaktu SD di SDN Karang Pawitan II Karawang, SMPN I Karawamg, dan SMAN 3 KARAWANG aktif mengikuti kejuaraan seni dan olahraga hingga tingkat provinsi. Tahun 1999-2008 aktif sebagai Atlit Panjat Tebing Kabupaten Karawang dengan beberapa prestasi yang di raih seperti Medali Emas Pada Porprov Jabar 2006 kategori speed (kecepatan) perorangan putri, dan hingga 2008 menjadi Atlit Jawa Barat pada PON di Kalimantan Timur dan meraih medali perak pada kategori kecepatan estatafet putri dan memutuskan untuk gantung sepatu dan harnest dari aktivitas sebagai atlit. Di tahun 2009 memutuskan untuk beralih mengamalkan ilmu yang didapat di bangku kuliah melamar sebagai dosen pada salah satu perguruan tinggi yang ada di Kabupaten Karawang yang saat itu membuka program studi baru yaitu program studi Ilmu Pemerintahan. Penulis menempuh studi S1 di prodi Ilmu Pemerintahan UNJANI-CIMAHI, S2 Ilmu Pemerintahan UNJANI-CIMAHI, Dan memperoleh Beasiswa BPPDN dari Kemenristekdikti program S2 Kebijakan Publik UNPAD-BANDUNG dan S3 Ilmu Pemerintahan UNPADBANDUNG, aktivitas hingga saat ini sebagai dosen tetap di prodi Ilmu Pemerintahan, Fakultas Ilmu Sosial dan Ilmu Politik (FISIP), Universitas Singaperbangsa Karawang. 